Copyright @ 2016 by Academic Publishing House Researcher

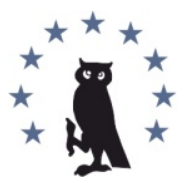

Published in the Russian Federation

Crusader

Has been issued since 2015 .

ISSN: $2409-6288$

E-ISSN: 2413-7502

Vol. 4, Is. 2, pp. 88-94, 2016

DOI: $10.13187 /$ crus.2016.4.88

www.ejournal29.com

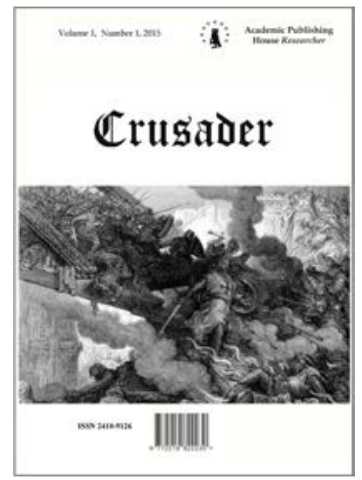

UDC 94(476) + 94(430) + 94(438) + 355.4

\title{
The Knight of Teutonic Order Heinrich von Plotzke
}

\author{
Ruslan B. Gagua ${ }^{\text {a }}$ * \\ a Polesski State University, Republic of Belarus
}

\begin{abstract}
The present article is devoted to life path of Knight Heinrich von Plotzke - one of the highest dignitaries of the Teutonic Order. According to the author, Heinrich von Plotzke played an important role in increasing the power of the state of the Teutonic Order in Prussia and distinguished himself as a manly warrior and a talented commander.

Heinrich von Plotzke made a brilliant career in the Teutonic Order, starting to serve as an ordinary knight-brother and then at different times occupying the post of provincial commander, lend master in Prussia, Grand Commander and Grand Marshal.

A significant part of his life Heinrich von Plotzke spent in battles and military campaigns. In Prussia, he participated in 15 military expeditions and 4 battles.

He arrived to Prussia in the difficult times for the Crusader's state and has achieved outstanding results in the solution of military issues that arose in this region. Heinrich von Plotzke managed to organize an effective system of a national defense.

Heinrich von Plotzke can be attributed to a number of those historical persons who made a significant impact on the history of the Teutonic Order and the Baltic region.

Keywords: Teutonic knights, Grand Duchy of Lithuania, Heinrich von Plotzke, Prussia, Middle Ages, Grand Commander, the battle of Woplawki.

\section{Introduction}

One of the key features of the historical science is its close connection with the specific destinies of billions of people. An understanding of certain historical events is simply impossible without understanding of life, actions, and individual aspirations. Attempts to reduce the historical process to the impersonal objective laws were ineffective. This is not surprising. European rationalism with its desire to arrange the world on a reasonable basis crashed like fragile crystal vessel fallen to the stone floor against merciless and bloody events of revolutions, wars and other social disasters which opened up the irrational dominant of human existence like surgical scalpel.

In this regard, the particular relevance has an appeal of the researches to such a huge layer of the past, as an individual existence of historical personalities. The life of the actors of the historical process requires a systematic, comprehensive and exhaustive research, followed by the publication
\end{abstract}

\footnotetext{
* Corresponding author

E-mail addresses: gagua@tut.by (R.B. Gagua)
} 
of biographies as famous and colorful characters as "small" people, who also were the creators of history.

A significant impact on the course of the history of a few nations of Eastern and Central Europa had Heinrich von Plotzke. He didn't only implement a series of reforms in the State of the Teutonic Knights but also waged successful wars against Grand Duchy of Lithuania and Samogitia and on Belarusian lands. Nevertheless, his biography was not enlighten sufficiently in historical literature: the information about Heinrich von Plotzke is sporadic and discrete. Some data about him, published by some researchers does not correspond the reality. For example, Theodore Narbutt mistakenly thought that Heinrich was born in the Polish town Plock (Narbutt, 1838: 432).

Described above set of problems determines the main purpose of the present article - the correction of this historiographical gap.

\section{The sources}

The main sources for writing the biographical sketch about Heinrich von Plotzke are chronicles of Peter von Dusburg and Nikolaus von J eroschin, written in Prussia in XIII century as well as rhymed chronicle of Wigand von Marburg, who was the herald of Konrad von Valenrode, one of the Grand Master of the Teutonic Order written in XIV century (Gagua, 2013: 110-113).

\section{Results}

\subsection{The beginning of the service in the Teutonic Order}

Heinrich von Plotzke was born in the Saxony's settlement Plötzkau in ministerial family Brandenburg's Margraves house. He joined the Teutonic Order in about 1286, and initially served in ballei Thuringia where he was acting as the provincial commander in Altenburg since 1286, and the provincial commander in Halle since 1287.

He arrived to Prussia around 1300 and was known according to the sources as provincial commander in the Order's castle Balga since 1304 (Dorna, 2004: 209; Petri de Dusburg, 1861: 173).

In 1306 Heinrich von Plotzke was elected by Chapter of Orders as a lend master of Prussia. When Siegfried von Feuchtwangen relocated a residence of the grandmasters from Venice to Marienburg, the position of the lend master of Prussia was eliminated, and Heinrich von Plotzke was appointed to the position of the Grand Commander (Dorna, 2004: 209).

For the first time Heinrich von Plotzke managed to show his leadership talent in 1311, after he defeated the army of Grand Duke of Lithuania Vytenis at the Battle of Woplawki (Gagua, 2015: 23-38).

\subsection{The battle of Woplawki}

February 23, 1311 the army of the Grand Duchy of Lithuania 4,000 warriors strong devastated and robbed at first Natangia and then Sambia. Otto von Bergau in Natangia and Friedrich von Lichtenberg in Sambia urgently began to collect the militia for «Landwehr» - the country's defense. At the same time, the Grand Commander Heinrich von Plotzke, acting in Marienburg on the position of dying Grand Master Siegfried von Feuchtwangen, sent couriers to Insterburg and Ragnit with an appeal to take to arms (Gagua, 2015: 26-29).

After conquering a part of Prussia, Vytenis and his army with a huge loot and 500 captives headed back to the country borders. Knights of the Order Friedrich von Lichtenberg and Otto von Bergau headed the local militia, started to chase him but unsuccessfully. Sambian squad of Friedrich von Lichtenberg turned to the north at the Masurian lakes and devastated the Pagraude land. The squad from Natangii headed by Otto von Bergau came to Grodno suburbs and robbed them. Then both troops successfully returned to Prussia (Gagua, 2015: 26- 29).

Having learnt about the looting of Pograude and the Grodno's castle surrounding area, Vytenis, returned to Aukštaitija at that time and, making sacrifices to pagan gods in gratitude for a successful campaign, got into a rage. He raised his army and entered into the land of the Teutonic Order again.

April 3, 1311 Vytenis at the head of 4,000 people rushed into Warmia. According to the Order's chronicler Peter von Dusburg, there were nothing left undestroyed in the lands of the Bishop of Warmi, except one castle and one town, after the invasion of the Grand Duchy of 
Lithuania warriors. All other villages were burned or destroyed. During a few days only, Warriors of Vytenis managed to took a big spoil and take captive 1,200 people (Gagua, 2015: 29).

After the devastation of Warmia Vytenis was returning through Barta back to his lands. On the $6^{\text {th }}$ of April his troops camped in a field near the village Woplawki. The camp was placed on the hill and fortified from all sides with the felled trees.

In the military camp Vytenis tried to turn captured Christians to paganism. He tried to show the infirmity of the Christian God and to emphasize the power and might of the pagan deities. The Lithuanian Duke gathered the Christians in front of him and forced captives to recognize his domination over them and to fight against other Christians under his banners (Gagua, 2015: 29).

Finally, Heinrich von Plotzke managed to gather the army of about 2,500 people and in the morning of April 7, they came up to the military camp of Vytenis.

The front squad of the Teutonic Knights, headed by Gunther von Arnstein, immediately entered the battle and attacked the Lithuanian Duke camp, but were stopped by the guard squad. Sheltered behind the felled trees, the Grand Duchy of Lithuania's warriors killed several dozens of Crusaders using bows and darts, and stopped the attack (Gagua, 2015: 31- 33).

Then Gunther von Arnstein changed his tactics: he ordered to shoot with bows into the sheltered in the camp guards and not to attack until the arrival of the main forces of the Order.

When the main forces of the Crusader's army approached Woplawki, Heinrich von Plotzke, who headed the attack, broke through the defense of the camp entrance and burst inside with his people. The defenders were embarrassed and fled away in panic (Gagua, 2015: 33- 35).

Many runaways were forced by the chasers into a nearby lake where they were killed or drown. It was a crushing defeat for the Lithuanian duke. However, Vytenis with several nobles managed to escape, but according to the legend, duke was seriously wounded in the head (Gagua, 2015: 34-35).

The Grand Commander immediately went with the squad to Grodno. But when he learned from spies about an ambush waiting for him, decided to return to Marienburg (Petri de Dusburg, 1861: 176- 177).

\subsection{The military campaign in Salsenikka}

In the same year, Heinrich von Plotzke managed to carry out a successful military expedition against the Grand Duchy of Lithuania. Having collected the considerable army of not less than 150 brothers of the Order, he went to Grodno.

On their way the Crusaders captured a few spies of the Lithuanian duke. They told that in Salsenikka, a land to the north from Grodno, nobody expected the attack, and moreover 500 Vytenis' hunters were getting ready for the Grand duke's hunt on the left bank of the river Neman. Then the army of Heinrich von Plotzke turned to the north, where killed the hunters and on the $11^{\text {th }}$ of April crossed Neman.

Twelve brothers of the Order with 2 thousand of people were left on the riverbank for the protection of ships and provisions. The rest of the army devastated the suburbs, burned three castle and on the next day, 12 April, returned to the land of the Order with prey and captives (Petri de Dusburg, 1861: 178; Die Kronike, 1861: 580).

As we can see, Heinrich von Plotzke quickly reacted to the information received from spies decisively changing his initial military plans. He was a brave, decisive and smart man.

\subsection{The building of the castle Hristmemel and attempts to capture Bisena}

The success of Heinrich von Plotzke in the war against the Grand Duchy of Lithuania allowed the Teutonic Order to move further into the surroundings of river Neman. In 1313 the Grand Master Karl von Trier disposed to build on the bank of Neman another Castle of Order, named Hristmemel (Petri de Dusburg, 1861: 178- 179). It was built in April (Die Kronike, 1861: 581- 582) in front of the Lithuanian castle Bisena, which was one of the outposts in the struggle with the Crusaders. The new castle was located not far from fortresses of the Grand Duchy of Lithuania Yunigeda and Pista. Therefore, Hristmemel took an important strategic position and place in the organization of the Crusades into the enemy's land (Batura, 1986: 185, 191).

In the same year Heinrich von Plotzke was appointed on the position of Grand Marshal with residence in Konigsberg Castle. Having gathered the army in Konigsberg, he arrived in 
Hristmemel, and tried to take over Biesena castle. The Crusaders built a bridge of ships, which connected one of the River Island with the right bank of Neman where the Lithuanian fortress was located. Over the bridge to Biesena they delivered war machines and supplies for the troops. However, despite the use by the Crusaders of the battering rams, the siege was unsuccessful and was soon finished due to a big quantity of killed and wounded warriors on both sides (Petri de Dusburg, 1861: 179).

Having returned to Konigsberg, Heinrich von Plotzke again recruited the militia in Natangia and in Sambia and, having brought it into Hristmemel, repeatedly tried to capture Bisena. The second expedition also did not satisfy the Crusaders: Bisena withstood the assault, although both its outskirts were burned (Petri de Dusburg, 1861: 180).

\subsection{Military expeditions in Medininkai}

The new 1314 year Heinrich von Plotzke began with two military campaigns to Samogitia.

At the beginning of J anuary, the Grand Marshal led the Crusaders to Medininkai. While the Crusader squad stopped for overnight near the border before the invasion into the Grand Duchy of Lithuania, several Samogitians penetrated into the tent of sleeping Heinrich von Plotzke. They killed four people and stole two warhorses. Then they disappeared, remained unnoticed. Angry with what happened at night the grand marshal crossed the border at dawn, devastated land Samogitia for forty kilometers inland, killed and captured up to 700 people. After the devastation of the land the squad of Heinrich von Plotzke returned to the possessions of Order with the big prey (Petri de Dusburg, 1861: 180; Die Kronike, 1861: 583- 584).

The second military expedition to Samogitia was undertaken by Grand Marshal less than in a month after the J anuary campaign.

February 2, the Crusaders entered into the land Medininkai and raided the castle Sisditen where they incurred significant losses. Although the castle defenders had 19 persons killed, among whom was a representative of the local nobility - Samogitian Nobile Masin's brother, they withstood a fierce storm of the fortress and did not surrender. The Crusaders lost in the assault of Sisditen three brothers of the Order - Ulrich von Tetinger, Rebodon von Isenburg and Heinrich Ruthen, and four Prussians mercenaries. Then Heinrich von Plotzke ordered to stop the assault and quit a siege. After that, the Crusaders plundered the suburbs of Sisditen, and returned to their lands (Petri de Dusburg, 1861: 180).

\subsection{Crusade to Novogrudok}

The first major shock for Heinrich von Plotzke, apparently, was autumn campaign to Novogrudok, controversial by its results for the Crusaders. The second most important city in Grodno region was located enough far away from the borders of Duchy. During a long time, Novogrudok had not been subjected to any attacks. In this connection its residents felt relatively safe, unlike inhabitants of border town Grodno, where the war became a part of everyday life for the local population.

The crusade deep into the enemy territory had some difficulties: the Crusaders had to overcome about 400 kilometers. Almost half of the way they had to move through the deserted and rugged Galindian forest and enemies land. Heinrich von Plotzke by getting rid of everything that slows the movement planned to achieve Novogrudok quickly, having left aside the Grodno Castle. That is why on the way to the lands of the Grand Duchy of Lithuania the protected storage of food supplies was created. It was supposed to be used after returning. The second storage with 30 armed guards was built on the border with the Grand Duchy of Lithuania near Grodno. Also there were 1,500 horses left, which probably served as pack animals (Petri de Dusburg, 1861: 180-181).

Having quickly approached to Novogrudok, the Crusaders captured the city and razed it to the ground. The next day, Heinrich von Plotzke together with his warriors started the assault on Novogrudok castle, well-fortified and located on a hill with steep slopes. During the attack, many warriors on both sides were killed. Many of them were hardly wounded and later died.

Heinrich von Plotzke saw the futility of the attempted assault and clearly understood that the siege of the castle could last for a long time. Grand Marshal did not dare to stay further on the enemy territory, far from the borders of Prussia, and gave order to return (Die Kronike, 1861: 584585). 
But on the way back his soldiers met unforeseen and fatal difficulties: when approached to the food storage near the border, the Crusaders found that guards were killed by a squad of Grodno Castellan David. All supplies and horses were seized (Petri de Dusburg, 1861: 181).

David also found the second storage with supplies left by Heinrich von Plotzke in the forest for its using on his way back. David's people killed the guard, took the food and went back to the well-fortified Grodno castle, not daring to fight against the crusaders in an open-field battle.

The situation did not promise anything good for the army of the Teutonic Order. In the army of Heinrich von Plotzke people started to starve. The Knights were forced to eat their warhorses. Some of the warriors died of malnutrition, and some were so weak that died just after returning home (Petri de Dusburg, 1861: 181; Die Kronike, 1861: 585- 586).

The consequence of the Novogrudok campaign, unsuccessful for the Teutonic Order, was the temporary reduction of military activity of the Crusaders: during the next 1315 they had to defend themselves, and Heinrich von Plotzke did not take any military expedition neither in the land of the Great Duchy of Lithuania nor against Samogitians.

\subsection{The resumption of military activity}

Nevertheless, next year the Teutonic Order resumed its attacks: in winter 1316 Heinrich von Plotzke with his army ravaged and plundered Pastovia where his army killed and captured 500 people (Petri de Dusburg, 1861: 182; Die Kronike, 1861: 587).

After Grand Marshal returned to his residence in Königsberg Castle, he met a lot of pilgrims from Western and Central Europe, which had arrived in Königsberg to take part in a campaign against the pagans. Heinrich von Plotzke led them to Samogitia and enter into the land Medininkai. The guests lost many warriors in the battle at the castle Medevyage: pilgrim squad under the command of the Count of Berg lost 50 people (Petri de Dusburg, 1861: 183; Die Kronike, 1861: 587-588).

In 1317, Heinrich von Plotzke headed three military expeditions to the lands of the Grand Duchy of Lithuania.

The first campaign ended inefficient because his army had to go back to Prussia due to unfavorable weather conditions, not taking part in military attacks (Petri de Dusburg, 1861: 183).

One of the squads, consisted of 60 warriors under the command of Albert von Hagen, managed to kill 80 Lithuanians and captured the family of Samogitian noble Sudarg. However, for the other two squads the Crusade was unsuccessful: Friedrich von Libentsal's group, consisted of 150 warriors, unlucky stormed the castle of Gediminas - the brother of the Grand Duke of Lithuania Vytenis. The main forces, headed by the Grand Marshal himself, together with troops under the command of the brothers of the Order Hartmann and Friedrich Kvits which were joined him, got lost and could not significantly damage the enemy (Petri de Dusburg, 1861: 183- 184; Die Kronike, 1861: 588- 591).

The third autumn campaign ended September 22, 1317 with the battle on field Kalsen. September 21 Heinrich von Plotzke with army of 1,500 troopers crossed the Neman River and dismounted. Trying to appear suddenly at Yunigeda they silently crept through the Vint forest and at dawn attacked the castle walls. However, the castle garrison had been warned about the attack and met the attackers fully armed. Moreover Yunigeda defenders warned all about attack by making a fire on the one of the tower castle.

Having understood that they would not be able to capture the castle the Crusaders burned the suburbs of Yunigeda and returned to Kalsen field, where they were met by ready to fight army of the Grand Duchy of Lithuania. The bloody battle ended without results: neither of the parties won. On both sides there were many wounded and several dead warriors (Petri de Dusburg, 1861: 184).

Thus, none of the military campaigns of 1317 of Heinrich von Plotzke was significantly successful.

At the 1318 and 1319 Grand Marshal organized and headed some military campaigns to the lands of the Grand Duchy of Lithuania to the castles Yunigeda and Pista. Both campaigns finished with burning of the castles suburbs, but the castles were not captured (Petri de Dusburg, 1861: 184- 185; Die Kronike, 1861: 593). 


\subsection{The last battle of the Grand Marshal}

The next year became fatal for Heinrich von Plotzke. J uly 27, 1320 the Grand Marshal at the head of the army consisted of 40 brothers of the Order, cavalrymen of Sambian episcopate and Commandry of Ragnit, invaded into the Medininkai. While the front troops of crusaders dispersed, devastating and plundering the territory of Samogitia, the main forces with the Grand Marshal faced the unexpected attack of the Samogitians. The enemies rapidly surrounded the Crusaders into the deadly ring. In the combat 29 brothers of the Order fell dead, including Heinrich von Plotzke, who in his last battle according to Nikolaus von J eroschin "fought with the courage of a lion" (Die Kronike, 1861: 591).

The rest of the Crusader's army ran for safety. Many days they were wandering in the hairy forest. Vogt of Sambia Gerhard Rude, captured by Samogitians had been sacrificed to pagan gods in gratitude for the victory: he was burned alive on horse armed cap-a-pie (Petri de Dusburg, 1861: 185).

\section{Conclusion}

Heinrich von Plotzke made a brilliant career in the Teutonic Order, starting to serve as an ordinary knight-brother and then at different times occupying the post of provincial commander, lend master in Prussia, Grand Commander and Grand Marshal.

He arrived to Prussia in the difficult times for the Crusader's state and has achieved outstanding results in the solution of military issues that arose in this region. Heinrich von Plotzke managed to organize an effective system of a national defense.

A significant part of his life Heinrich von Plotzke spent in battles and military campaigns. Only in Prussia, he participated in 15 military expeditions and 4 battles.

Heinrich von Plotzke dead with the sword in his hand, like a warrior. The fortune of War was not always on his side, but Heinrich von Plotzke showed himself as a brave and extraordinary commander, using the latest achievements of a military art of the time.

Undoubtedly, Heinrich von Plotzke can be attributed to a number of those historical persons who made a significant impact not only on the history of the Teutonic Order but also on many surrounding lands, including the territory of modern Lithuania, Belarus, Russia and Poland.

\section{References}

Batura, 1986 - Batura R.K. (1986). Oborona pravoberezh'ya Nizhnego Nemana protiv agressii Tevtonskogo ordena (XIII - nachalo XIV v.) [The defense of the right bank of the Lower Niemen against the aggression of the Teutonic Order (XIII - beginning of XIV century.)]. Drevneishie gosudarstva na territorii SSSR. Materialy i issledovaniya. 1985 g. Moskva. pp. 185- 192.

Di Kronike, 1861 - Di Kronike von Pruzinlant des Nicolaus von J eroschin / Scriptores rerum Prussicarum / hrsg. von T. Hirsch, M. Töppen, E. Strehlke. Bd. I. Leipzig. 1861. pp. 291- 624.

Die Chronik, 1863 - Die Chronik Wigands von Marburg // Scriptores rerum Prussicarum / hrsg. von T. Hirsch, M. Töppen, E. Strehlke. Bd. II. 1863. pp. 429-662.

Dorna, 2004 - Dorna M. Bracia zakonu krzyżackiego w Prusach w latach 1228-1309. Poznań. 2004. 430 p.

Gagua, 2013 - Gagua R.B. (2013). Letopisnye soobshcheniya o bitve pri Voplavkakh 7 aprelya 1311 goda [The chronicle reports on the battle of Voplavkah April 7, 1311] // Aktual'nye problemy istochnikovedeniya: materialy mezhdunar. nauch.-prakt. konf. $\mathrm{k}$ 135-letiyu so dnya rozhdeniya V. I. Pichety, Minsk-Vitebsk, 9-11 oktyabrya 2013 g. Vitebsk. pp. 110- 113.

Gagua, 2015 - Gagua R. (2015). The Battle of Woplawki: the Fall of Anticrusaders Campaigns of Grand Duke of Lituania Vitenes. Crusader. Vol. (1) Is. 1. pp. 23- 38.

Gagua, 2016 - Gagua R.B. (2016). Soobshchenie khronik Tevtonskogo ordena o bitve pri Voplavkakh [The report of chronicles of the Teutonic Order about the Battle of Voplavkah]. Vēsture Avoti un cilvēki. Daugavpils. 2016. pp. 66- 74.

Narbutt, 1383 - Narbutt T. (1838). Dzieje Narodu 1861 litewskiego. T. IV. Wilno. 737 p.

Petri de Dusburg, 1863 - Petri de Dusburg Chronicon terrae Prussie // Scriptores rerum Prussicarum / hrsg. von T. Hirsch, M. Töppen, E. Strehlk. Bd. I. Leipzig. 1861. pp. 3- 219. 
УдК 94(476) + 94(430) + 94(438) + 355.4

\section{Рыцарь Тевтонского ордена Генрих фон Плоцке}

Руслан Борисович Гагуа ${ }^{a}$,

а Полесский государственный университет, Республика Беларусь

Аннотация. В представленной статье рассматривается жизненный путь одного из высших сановников Тевтонского ордена рыцаря Генриха фон Плоцке. По мнению автора, Генрих фон Плоцке сыграл значительную роль в повышении мощи государства Тевтонского ордена в Пруссии и проявил себя как мужественный воин и талантливый полководец.

Генрих фон Плоцке сделал блестящую карьеру в Тевтонском ордене, начав службу рядовым братом-рыцарем и в различное время занимая должности комтура, лянтмайстра в Пруссии, великого комтура и великого маршала.

Значительную часть своей жизни Генрих фон Плоцке провёл в сражениях и военных кампаниях. В Пруссии он принял участие в 15 военных экспедициях и 4 битвах.

Он прибыл в Пруссию в тяжёлые для государства крестоносцев времена и добился выдающихся результатов в увеличении военного влияния в регионе. Генрих фон Плоцке сумел организовать эффективную систему обороны края.

Генрих фон Плоцке может быть отнесён к числу тех исторических персоналий, которые оказали значительное влияние на историю Тевтонского ордена и Прибалтийского региона.

Ключевые слова: Тевтонский орден, Великое княжество Литовское, Генрих фон Плоцке, Пруссия, Средние века, великий комтур, битва при Воплавках.

\footnotetext{
* Корреспондирующий автор Адреса электронной почты: gagua@tut.by (Р.Б. Гагуа)
} 